\title{
HUMAN RESOURCE MANAGEMENT IN SELECTED HEALTH SERVICE PROVIDERS IN THE CZECH REPUBLIC IN THE CONTEXT OF THE CURRENT MODERN HR TRENDS
}

\author{
[Ř́zení lidských zdrojů u vybraných poskytovatelů zdravotních služeb v České \\ republice v kontextu současných moderních personálních trendů]
}

\author{
Jiř́ Bejtkovský1 \\ ${ }^{1}$ Univerzita Tomáše Bati ve Zlíně, Fakulta managementu a ekonomiky, Mostni 5139, 76001 Zlín \\ Email: bejtkovsky@fame.utb.cz.
}

\begin{abstract}
This paper focuses on human resource management in selected health service providers in the Czech Republic in the context of the current modern HR (human resource) trends. The main goal of this contribution was to characterize and, subsequently, confront the current modern HR trends in the research area of human resource management of a health care services provider's HR managers in the Czech Republic. The article presents some of the outcomes of primary quantitative and qualitative research. This research was carried out in 2016 and in 2017 from the sample of 47 respondents. One research hypothesis and one research question have been defined. The verification or rejection of null research hypothesis was done through the statistical method of the Pearson's Chisquare test. The results of the research came along with the finding that there is no statistically significant dependence between current implementation of the modern HR trends in selected health service providers in the Czech Republic and the number of employees in selected health service providers in the Czech Republic.
\end{abstract}

Keywords: care of employees, diversity management, employer brand, e-recruitment, global workplace, health service providers, HR outsourcing, work-life balance.

JEL classification: I10, J24, M12

Doručeno redakci: 30.10.2017; Recenzováno: 3.11.2017; 13.11.2017; Schváleno k publikování: 13.12.2017

\section{Úvod}

Kociánová (2012) konstatuje, že se řízení lidských zdrojů (personální řízení, řízení zaměstnanců) $\mathrm{v}$ korporacích - firmách, institucích, organizacích, podnicích, úřadech, společnostech vždy vyvíjelo v souladu s určitým sociálním a ekonomických kontextem konkrétního období. V souvislosti vnějšími vlivy i vnitřními podmínkami korporací se měnily určité personální činnosti, postupem času rostly a nadále budou růst nároky na personální specialisty, personální manažery a další zaměstnance personální oddělení.

Časy, kdy byl nejdůležitějším a nejvýznamnějším aktivem každí korporace hmotný majetek, jsou již nenávratně pryč. Některé korporace dnes nevlastní vůbec žádné nemovitosti ani výrobní linky a zdrojem jejich aktivní konkurenční výhody se stali jejich lidé - jejich zaměstnanci (Vodák a Kucharčíková 2011).

Řízení lidského kapitálu (lidský zdrojů, zaměstnanců) se zabývá těmi činnostmi, které souvisí se zaměstnáváním a řízením lidí v korporacích - firmách, institucích, organizacích, podnicích, úřadech, společnostech. Zahrnuje činnosti týkající se strategického řízení lidských zdrojů, řízení lidského kapitálu, řízení znalostí, společenské odpovědnosti korporace, rozvoje korporace, zabezpečování lidských zdrojů (přes proces plánování potřebného počtu zaměstnanců, získávání, výběru zaměstnanců až po oblast řízení talentů), řízení pracovního výkonu, hodnocení a odměňování zaměstnanců, vzdělávání a rozvoje zaměstnanců, 
zaměstnaneckých a pracovně-právních vztahů, péče o zaměstnance a poskytování různých služeb zaměstnancům (Armstrong 2015).

Jak uvádí Maršíková a Myslivcová (2016), úspěšnost, výkonnost a konkurenční pozice dnešních moderních korporací nezávisí pouze na nabízených produktech či službách, které uspokojují rozmanitá přání a potřeby zákazníka či spotřebitele, ale také na tom, jak daná korporace vystupuje $\mathrm{v}$ roli zaměstnavatele, a jak se stará, a jakým způsobem přistupuje ke svým nejcennějším zdrojům, které má, tedy svým zaměstnancům.

Oblast zaměstnávání a celého procesu zaměřeného na samotného zaměstnance nejen u poskytovatelů zdravotních služeb by měla dnes, na počátku 21. století, respektovat a vnímat každého zaměstnance jako individualitu. Proto, aby byly požadované pracovní úkoly a výkony zaměstnanců produktivní, smysluplné, motivující a prŕnosné, je zapotřebí mít správné zaměstnance ve správný čas na správném místě. Management, HR specialisté či HR manažeři nejen u poskytovatelů zdravotních služeb by měli sledovat, inspirovat se a následně implementovat do svých personálních strategií různé druhy tuzemských a zahraničních trendů, mechanismů, procesů či postupů tak, aby vhodně, přměřeně a efektivně reagovali na současnou situaci na trhu práce.

Cílem př́íspěvku je na základě obsahové analýzy sekundárních informačních zdrojů, zejména pak vědecké literatury, definovat současné moderní trendy, které charakterizují oblast dnešního rrízení lidských zdrojů a následně tyto definované trendy analyzovat HR specialisty či HR manažery u vybraných poskytovatelů zdravotních služeb na území České republiky. Úvodní část příspěvku je zaměřena na teoretická východiska, prostřednictvím kterých jsou stanoveny vybrané současné moderní personální trendy. V další části je představena metodika výzkumu a následně prezentovány dílčí výsledky realizovaných marketingových výzkumů (kvantitativního a kvalitativního). V poslední části př́spěvku je uvedena diskuze ke zjištěným výsledkům a stanoven závěr celého př́spěvku. Primární data jsou získána prostřednictvím spolupráce s HR specialisty anebo HR manažery pracující u poskytovatelů zdravotních služeb na území České republiky.

\section{Teoretická východiska současných moderních personálních trendů}

Fried a Fottler (2008) tvrdí, že proces řízení lidských zdrojů u poskytovatelů zdravotních služeb je jedním z nejdynamičtějších oblastí. Vzhledem k tomu, že poskytovatelé zdravotní péče nemohou existovat bez lidí - zaměstnanců, kteří poskytují péči pacientům, a to jak přímo, tak nepřímo, je nábor a udržení kvalifikovaných zaměstnanců velmi závažná, prioritní a podstatná personální činnost. Nicméně dnešní poskytovatelé zdravotních služeb čelí mnoha výzvám, ale také nedostatku některých typů lékařù a zdravotních sester. Obzvláště naléhavou se stává skutečnost, že obyvatelstvo stárne a starší zaměstnanci opouštějí trh práce. V nadcházejících letech tedy bude zapotřebí větší počet kvalifikovaných, motivovaných, schopných, loajálních a zkušených zaměstnanců v oblasti zdravotních služeb.

Jak interpretuje v této souvislosti Naegler (2014), spokojenost pacientů, ale také zdravotnického personálu předpokládá vysokou úroveň a kvalitu léčby a služeb daného poskytovatele zdravotních služeb.

Pynes a Lombardi (2011) mimo jiné uvádí, že bude v rámci strategického řízení nejen u poskytovatelů zdravotních služeb zapotřebí zvážit následující skutečnosti: (1) jak se bude práce a pracovní zátěž nejen u poskytovatelů zdravotních služeb měnit $\mathrm{v}$ důsledku technologického pokroku a měnících se ekonomických, sociálních, kulturních a politických 
podmínek?, (2) jaké budou výsledky, následky a efektivnost těchto změn?, (3) jak budou navrženy a jakým způsobem budou fungovat oddělení, pracovní jednotky a pracovní místa nejen u poskytovatelů zdravotních služeb? Jakmile budou tyto otázky zodpovězeny, je dalším krokem identifikace dovedností, které budou muset zaměstnanci nejen u poskytovatelů zdravotních služeb mít, aby byla zajištěna konkurenceschopnost a výkonnost daného zaměstnavatele.

V oblasti řízení lidských zdrojů nejen u poskytovatelů zdravotních služeb se neustále objevují nové pokusy, jak tuto - nepochybně nejdůležitější - složku řízení korporací přizpůsobit aktuálně měnící se situaci v oblasti práce a podnikání a zejména pak měnící se situaci v oblasti pracovních sil. V současné práci postupně dochází k posunu od složky fyzické ke složce duševní. Nejvíce je to vidět v nárůstu požadavků na vědomosti, znalosti a dovednosti manuální práce, která stále více předpokládá využívání pokročilých technologií, například informačních. Současná pracovní síla proto musí být vybavena poměrně rozsáhlými a do hloubky směřujícími znalostmi a dovednostmi a vyznačuje se mnohem vyšší úrovní vzdělání, než tomu bylo v letech minulých (Armstrong 2011).

Z tohoto důvodu se mimo jiné objevují nové techniky, metody, trendy, principy, definice anebo pojmy, které oblast řízení lidských zdrojů výrazně ovlivňují či určitým způsobem mění, inovují, ba dokonce přetvářejí. Prostřednictvím obsahové analýzy sekundárních informačních zdrojů, zejména pak s pomocí vědecké literatury byly identifikovány následující vybrané současné moderní personální trendy: (1) aktivní péče o zdraví zaměstnancủ, (2) brand zaměstnavatele, (3) diversity management, (4) e-Recruitment a sociální sítě, (5) globální pracovní prostředí, (6) informační systém a důraz na využivání informačních technologií v oblasti řízení lidských zdrojů, (7) outsourcing vybraných personálních činností a procesů, (8) Work-life balance. S těmito vybranými současnými moderními personálními trendy v oblasti řízení lidských zdrojů bylo dále následně pracováno v rámci výzkumu primárního zejména pak kvantitativního a následně kvalitního marketingového výzkumu.

\subsection{Aktivní péče o zdraví zaměstnanců}

Zaměstnancům nejen u poskytovatelů zdravotních služeb by měla být věnována důsledná péče a pozornost, nebot' jsou to právě oni, kteří dávají do pomyslného oběhu další zdroje, které každý zaměstnavatel vlastní.

Ne každý zaměstnavatel si tuto skutečnost uvědomuje. Nicméně, jak prezentuje Schultz a Edington (2007), studie některých zdravotních rizikových faktorů naznačují, že náklady na ztrátu produktivity korporace přesahují náklady na lékařskou péči.

Na druhou stranu Ammendolia, Côté, Cancelliere, Cassidy, Hartvigsen, Boyle, Soklaridis, Stern a Amick (2016), v této souvislosti uvádějí, že péče, pozornost a programy zaměřené na aktivní podporu a nejen péči o zdraví zaměstnanců se značně liší svojí nabídkou a vůbec př́stupem každé korporace $\mathrm{k}$ této oblasti. Péče $\mathrm{v}$ sobě může zahrnovat programy na podporu zdraví zaměstnanců, ale také různé další služby, které se prímo zdravotního stavu zaměstnanců netýkají.

\subsection{Brand zaměstnavatele}

Dnešní trh práce, nejen tuzemský, ale i zahraniční, a samotné podnikatelské prostředí se dnes, na počátku 21. století, mění turbulentním tempem stejně tak, jako situace a klima na samotném trhu práce (Wahba a Elmanadily 2015). 
Backhaus a Tikoo (2004) tvrdí, že je značka zaměstnavatele považována za jedno z nejdůležitějších a cenných aktiv jakékoliv korporace. Představuje tak její snahu aktivně se propagovat jak uvnitř, tak mimo ni. Významnost značky zaměstnavatele stále roste a stává se tak populárním trendem nejen z hlediska řízení lidských zdrojů.

Pro většinu lidí je značka přímo spojena s názvem korporace, produkty, nabízenými a poskytovanými službami a konkrétním logotypem. Značku lze však využít i jako součást oblasti řízení lidských zdrojů za účelem přilákání nových zaměstnanců a zvyšování loajality zaměstnanců současných (Kunerth a Mosley 2011).

\subsection{Diversity management}

Dobusch (2017) prohlašuje, že ačkoli se v posledních desetiletích neustále rozšiřuje výzkum rozmanitosti lidských zdrojů, dopady řízení rozmanitosti na začleňování historicky znevýhodněných skupin na trhu práce jsou stále ještě bohužel v pochybnostech.

Každopádně Manoharan a Singal (2017) vypovídají, že úloha a implementace fillosofie diversity managementu do personálních politik nejen u poskytovatelů zdravotních služeb je a bude zapotřebí, a to $\mathrm{v}$ souvislosti $\mathrm{s}$ demografickými změnami, mezinárodní pracovní mobilitou a rozšiřováním geografických hranic. Rízení rozmanitosti pracovní síly má nejen svůj význam, ale také má pozitivní vliv na oblast inovací, konkurenceschopnosti a výkonnosti každé korporace.

Wise a Tschirhart (2000) v této souvislosti říkají, že zvýšená výkonnost jakékoliv korporace vychází z dosažení lepších pracovních výsledků a z užších interakcí mezi jednotlivci v dané korporaci. Takové mezilidské vztahy vyvolávají důvěru mezi jednotlivými zaměstnanci. Řízení rozmanitosti tak působí jako katalyzátor při vytváření důvěry a vnímání spravedlnosti mezi zaměstnanci nejen u poskytovatelů zdravotních služeb.

\section{4 e-Recruitment a sociální sítě}

Mariani, Curcuruto a Zavalloni (2016) prezentují skutečnost, že v posledních letech se online nábor (e-Recruitment) zaměstnanců stává převládající a úspěšnou praxí v oblasti řízení lidských zdrojů po celém světě.

LinkedIn je dnes jednou z vedoucích sociálních sítí, která je zaměřena na profesní využití. Tato sociální sít' je vysoce ceněna specialisty nejen voblasti IT, ale také voblasti HR i samotnými uživateli (Silva, Silva a Martins 2017).

Tussayadiah a Fesenmaier (2009) v této souvislosti doplňují, že sociální sítě, sociální média, blogy, videa, Wikis, fóra a diskusní místnosti umožňují jednotlivcům, komunitám i samotným korporacím vytvářet a sdílet informace a zkušenosti online, čímž se více přiblížit potenciálním zaměstnancům.

\subsection{Globální pracovní prostředí}

Windscheid, Bowes-Sperry, Mazei a Morner (2017) tvrdí, že jakákoliv různorodost pracovní síly a pracovního prostředí nejen u poskytovatelů zdravotních služeb může dnes, v prostředí mezinárodní konkurence nejen na trhu práce a globalizovaném korporátním prostředí vést k trvalé a jasné konkurenční výhodě a představovat tak zajímavou výzvu dnešního korporátního světa. 
Globální pracovní síla a prostředí může vykazovat rozmanitost na základě pohlaví, věku, vzdělání, národnosti, rasy, etnické příslušnosti, náboženství, zdravotního postižení a tak podobně (Manoharan a Singal 2017).

\subsection{Informační systém a důraz na využívání informačních technologií v oblasti řízení lidských zdrojů}

Egerová a Eger (2017) uvádějí, že v posledních letech hraje důležitou roli v oblasti personálních postupů a procesů využívání informačních technologií, zejména pak korporátních webových stránek. Webové stránky jakékoliv korporace mohou v rámci oblasti řízení lidských zdrojů sloužit k samotné propagaci v kontextu značky dobrého zaměstnavatele nebo dále také k náboru potenciálních uchazečů o zaměstnání.

Je zřejmé, že samotný technologický pokrok a využívaní nových moderních technologií či informačních systémů změnily, mění a i nadále budou měnit strukturu nejen u poskytovatelů zdravotních služeb, ale ve všech korporacích. V některých př́ípadech může docházet k omezování potřebného počtu zaměstnanců či se na druhou stranu mohou objevovat pracovní místa či pracovní pozice nové, kde bude zapotřebí vysoce kvalifikované pracovní síly (Pynes and Lombardi 2012).

\subsection{Outsourcing vybraných personálních činností a procesů}

Outsourcing nejen personální činností anebo procesů nastává tehdy, kdy korporace převede své vnitřní aktivity na korporaci nezávislého dodavatele pomocí dlouhodobého smluvního vztahu (Belcourt 2006; Johnson, Wilding a Robson 2014).

Outsourcing ovšem nemusí být vždy bezrizikový. Rizika mohou spočívat v nerealizovaném snížení nákladů, ztrátě kontroly nad konkrétní činností nebo procesem, ztrátě strategické flexibility a podobně (Susomrith a Brown 2017).

Klaas, McClendon a Gainey (2001) popisují čtyři základní činnosti či kategorie aktivit v oblasti řízení lidských zdrojů, které jsou často outsourcovány: (1) všeobecné personální činnosti, (2) transakční činnosti, (3) činnosti v oblasti lidského kapitálu, (4) nábor a výběr zaměstnanců.

\subsection{Work-life balance}

Jak uvádí Bryan a Sevilla (2017), filosofie označovaná jako Work-life balance spočívá na myšlence, kdy pohodlí a volba v pracovní době je jádrem rovnováhy mezi pracovním a soukromým životem.

Politiky rovnováhy mezi pracovním a soukromým životem zaměstnance jsou formální nebo neformální politiky, postupy nebo přístupy $\mathrm{v}$ oblasti řízení lidských zdrojů navržené korporací, které mají zaměstnancům pomáhat integrovat jejich práci či pracovní povinnosti a soukromý život (Ngo, Foley a Loi 2009).

Eby, Casper, Lockwood, Bordeaux a Brinley (2005) tvrdí, že rovnováha mezi pracovním a soukromým životem zaměstnance pozitivně souvisí s jeho konkrétními pracovními postoji a jeho výkonností.

\section{Cíl, metodika a data}

Příspěvek je zaměřen na oblast řízení lidských zdrojů, zejména pak na současné moderní personální trendy, které jsou definovány na základě sekundárních informačních zdrojů. Dále 
jsou tyto definované personální trendy analyzovány prostřednictvím kvantitativního a kvalitativního marketingového výzkumu u vybraných poskytovatelů zdravotních služeb v České republice.

Hlavním cílem př́spěvku tedy je na základě obsahové analýzy vědecké literatury charakterizovat současné moderní personální trendy a poté tyto trendy konfrontovat se současným personálním řízení u vybraných poskytovatelů zdravotních služeb v České republice.

Teoretická východiska zpracovaných současných moderních personálních trendů jsou postavena na studiu odborných monografických a seriálových publikacích a jejich následné analýze. Seriálové publikace byly vyhledány a analyzovány pomocí elektronických databází, zejména pak pomocí příspěvků uvedených v databázi Scopus a databázi Web of Science. Za pomoci obsahové analýzy tak mohlo být definováno celkem osm současných moderních personálních trendů, se kterými se dále pracovalo v rámci primárního výzkumu.

Základní primární zdroje informací, které sloužily k verifikaci stanovené výzkumné hypotézy a k zodpovězení výzkumné otázky byly získány díky kvantitativnímu a kvalitativnímu marketingovému výzkumu. $\mathrm{V}$ tomto příspěvku jsou tak uvedeny pouze některé dílčí výsledky provedených marketingových výzkumů. Kvantitativní výzkum byl realizován pomocí anonymního dotazníkového šetření (v elektronické i papírové podobě) v roce 2016, jehož respondenti byli HR specialisté anebo HR manažeři u vybraných poskytovatelů zdravotních služeb na území České republiky. Každý dotazník měl celkem dva základní oddíly. První část dotazníku byla vždy zaměřena na jeden $\mathrm{z}$ osmi konkrétních současných moderních personálních trendů a následně jeho využívání u vybraného poskytovatele zdravotních služeb a také na užitečnost tohoto trendu z pohledu osloveného HR specialisty anebo HR manažera. Tato část měla dohromady dvacet čtyři otázek. Druhá část dotazníku byla zaměřena na otázky identifikační a také na doplňující informace a fakta, který souvisela s realizovaným výzkumem. V této části dotazníku bylo uvedeno celkem dvanáct otázek. Základní soubor představoval celkem 188 poskytovatelů zdravotních služeb. Touto první fází dotazníkového šetření se podařilo získat výzkumný vzorek o velikosti 32 respondentů. Jelikož bylo snahou získat co možná nejobjektivnější pohled na zkoumanou problematiku, realizovala se ještě druhá fáze dotazníkového šetření, a to v roce 2017. Podařilo se tak získat ještě devatenáct dotazníků. Jelikož nebyly čtyři získané dotazníky řádně vyplněny, musely být vyřazeny. Celkový výzkumný vzorek, se kterým se dále v rámci celého kvantitativního marketingového výzkumu dále pracovalo, představoval 47 respondentů (HR specialistů či HR manažerů u vybraných poskytovatelů zdravotních služeb). Lze tedy říci, že návratnost dotazníkové šetření byla $25 \%$. Verifikace navržené výzkumné hypotézy byla provedena pomocí statistické metody Pearson's Chi-square test.

Pro hlubší vědecké zkoumání výzkumného problému byl dále realizován také kvalitativní marketingový výzkum, který přinesl další zajímavé a podnětné informace a skutečnosti. Tento typ výzkum byl proveden prostřednictvím dvanácti polostrukturovaných interview s vybranými HR specialisty anebo HR manažery. Skutečnosti, které vyplynuly z kvalitativního, ale také kvantitativního marketingového výzkumu sloužily pro zodpovězení definované výzkumné otázky. V rámci zpracování sekundárních, ale také primárních informací a pro definování výzkumných závěrů byly aplikovány vybrané vědecké metody, jako je analýza, syntéza, indukce a také dedukce. 


\section{Výsledky a diskuze}

Prostřednictvím zpracování literární rešerše a následných teoretických východisek současných moderních personálních trendů byla formulována jedna výzkumná hypotéza (H1) a také jedna výzkumná otázka (VO1).

H1: Existuje statisticky významná závislost mezi současným využíváním moderního trendu v oblasti řízení lidských zdrojů u vybraných poskytovatelů zdravotních služeb v České republice a mezi počtem zaměstnanců u vybraného poskytovatele zdravotních služeb v České republice.

Výše uvedená výzkumná hypotéza $(\mathrm{H} 1)$ byla testována, verifikována, pomocí metody matematické statistiky, a to testem dobré shody - Pearsonův chí-kvadrát test. Pro následnou analýzu získaných výzkumných dat byl využit program SPSS Statistics.

VO1: Jakým způsobem je, v dnešním turbulentním a globálním prostředí, vnímána stále rostoucí tendence značky/brandu poskytovatele zdravotních služeb v České republice?

Výzkumný soubor dat a informací vedoucí ke splnění navrženého výzkumného cíle byl získán zejména prostřednictvím realizovaného dotazníkového šetření a polostrukturovanými interview s HR manažery u vybraných poskytovatelů zdravotních služeb na území České republiky.

Struktura vybraných poskytovatelů zdravotních služeb v České republice na základě počtu zaměstnanců je uvedena v níže uvedené tabulce (Tabulka 1).

Tabulka 1: Struktura vybraných poskytovatelů zdravotních služeb na základě počtu zaměstnanců

\begin{tabular}{|c|c|c|c|}
\hline Kategorie dle členění Evropské unie & $\begin{array}{c}\text { Interval (hranice) počtu } \\
\text { zaměstnanců }\end{array}$ & Absolutní četnost & Relativní četnost \\
\hline $\begin{array}{l}\text { Mikro poskytovatel zdravotních } \\
\text { služeb }\end{array}$ & $\begin{array}{l}\text { méně než } 10 \\
\text { zaměstnanců }\end{array}$ & 3 & $6,38 \%$ \\
\hline $\begin{array}{l}\text { Malý poskytovatel zdravotních } \\
\text { služeb }\end{array}$ & $\begin{array}{l}\text { méně než } 50 \\
\text { zaměstnanců }\end{array}$ & 10 & $21,28 \%$ \\
\hline $\begin{array}{l}\text { Střední poskytovatel zdravotních } \\
\text { služeb }\end{array}$ & $\begin{array}{l}\text { méně než } 250 \\
\text { zaměstnanců }\end{array}$ & 17 & $36,17 \%$ \\
\hline $\begin{array}{l}\text { Velký poskytovatel zdravotních } \\
\text { služeb }\end{array}$ & $\begin{array}{c}250 \text { a více } \\
\text { zaměstnanců }\end{array}$ & 17 & $36,17 \%$ \\
\hline \multicolumn{2}{|c|}{$\begin{array}{l}\text { Celkový počet oslovených respondentů u vybraných } \\
\text { poskytovatelů zdravotních služeb v České republice }\end{array}$} & 47 & $100,00 \%$ \\
\hline
\end{tabular}

Zdroj: Vlastní zpracování

Výzkumná hypotéza (H1): Existuje statisticky významná závislost mezi současným využíváním moderního trendu v oblasti řízení lidských zdrojů u vybraných poskytovatelů zdravotních služeb v České republice a mezi počtem zaměstnanců u vybraného poskytovatele zdravotních služeb v České republice.

H0: Neexistuje statisticky významná závislost mezi současným využíáním moderního trendu v oblasti řízení lidských zdrojů u vybraných poskytovatelů zdravotních služeb v České republice a mezi počtem zaměstnanců u vybraného poskytovatele zdravotních služeb v České republice. 
HA: Existuje statisticky významná závislost mezi současným využíváním moderního trendu v oblasti řízení lidských zdrojů u vybraných poskytovatelů zdravotních služeb v České republice a mezi počtem zaměstnanců u vybraného poskytovatele zdravotních služeb v České republice.

Údaje charakterizující výzkumnou hypotézu (H1) jsou prezentovány v níže znázorněné tabulce (Tabulka 2).

Tabulka 2: Verifikace výzkumné hypotézy (H1) pomocí testu dobré shody - Pearsonova chíkvadrát testu

\begin{tabular}{|c|c|c|c|c|c|c|c|}
\hline $\begin{array}{c}\text { H1: Existuje statisticky významná závislost mezi současným využíváním moderního trendu v oblasti } \\
\text { ŕ́zení lidských zdrojů u vybraných poskytovatelů zdravotních služeb v České republice a mezi počtem } \\
\text { zaměstnanců u vybraného poskytovatele zdravotních služeb v České republice. }\end{array}$ \\
\hline $\begin{array}{c}\text { Současný vybraný } \\
\text { moderní personální } \\
\text { trend }\end{array}$ & $\begin{array}{c}\text { Pearsonův } \\
\text { chí-kvadrát }\end{array}$ & df & $\begin{array}{c}\text { Hodnota } \\
\text { p-value }\end{array}$ & $\begin{array}{c}\text { Současný vybraný } \\
\text { moderní personální } \\
\text { trend }\end{array}$ & $\begin{array}{c}\text { Pearsonův } \\
\text { chí-kvadrát }\end{array}$ & $\begin{array}{c}\text { Hodnota } \\
\text { p-value }\end{array}$ \\
\hline $\begin{array}{c}\text { Aktivní péče o zdraví } \\
\text { zaměstnancú }\end{array}$ & 0,506 & 3 & 0,902 & $\begin{array}{c}\text { Globální pracovní } \\
\text { prostředí }\end{array}$ & 2,614 & 3 & 0,313 \\
\hline $\begin{array}{c}\text { Brand/značka } \\
\text { zaměstnavatele }\end{array}$ & 2,863 & 3 & 0,322 & Informační & 2,711 & 3 & 0,296 \\
\hline $\begin{array}{c}\text { Diversity } \\
\text { management }\end{array}$ & 4,284 & 3 & 0,232 & personálních procesů & 3,612 & 3 & 0,411 \\
\hline $\begin{array}{c}\text { e-Recruitment } \\
\text { a sociální sítě }\end{array}$ & 3,397 & 3 & 0,308 & Work-life balance & 4,012 & 3 & 0,368 \\
\hline
\end{tabular}

Zdroj: Vlastní zpracování v programu SPSS Statistics (2017)

Výše charakterizovaná výzkumná hypotéza $(\mathrm{H} 1)$ byla rozčleněna na jednotlivé dílčí části podle sledovaného současného moderního personálního trendu. Výsledky její verifikace platnosti ukazují, že hodnota testu dobré shody, p-value Pearsonova chí-kvadrát testu nezávislosti je pro každý stanovený vybraný současný moderní personální trend vyšší než stanovená hodnota 0,05 . Na hladině významnosti $5 \%$ se tak nezamítá hypotéza H0. Lze tedy říci, že neexistuje statisticky významná závislost mezi současným využíváním moderního trendu $\mathrm{v}$ oblasti řízení lidských zdrojů u vybraných poskytovatelů zdravotních služeb v České republice a mezi počtem zaměstnanců u vybraného poskytovatele zdravotních služeb v České republice.

V souvislosti s péčí nejen o zákazníky, ale také o zaměstnance dané korporace prezentují Chuang a Liao (2010) závěry svých realizovaných výzkumů, ve kterých tvrdí, že aktivní péče o zaměstnance vede ke zlepšení klimatu a atmosféry v korporaci a dále pak povzbuzuje a motivuje všechny zaměstnance k dosahování potřebných pracovních výkonů. Kashive a Khanna (2017) přicházejí se zjištěním, že se vysoce kvalifikovaní uchazeči o zaměstnání na nejistém trhu práce chovají velmi podobně jako spotřebitelé na přeplněném trhu. Proto doporučují, aby korporace využívaly svůj marketingový mix nejen v oblasti zákazníků, ale také v oblasti lidských zdrojů a ovlivňovaly tak pozitivní vnímají o sobě, jako subjektu úspěšného, vyhledávaného a vhodného zaměstnavatele. Koncept aktivní implementace diversity managementu do filosofie korporace vedle dle výzkumů Manoharana a Singala (2017) k její vyšší výkonnosti a tvorbě větší míry inovací. Trend e-Recruitmentu a sociálních médií v rámci recruitmentu bude dle Ladkin a Buhalise (2016) neustále nabývat na svém 
významu a to i v souvislosti s průmyslem 4.0. Ryan a Wessel (2015) prezentují výzkumné zjištění, že dnešní globální pracoviště musejí v oblasti řízení lidských zdrojů brát na zřetel globalizaci a její trendy, rozmanitost pracovní síly a moderní technologie. Dahlan, Dahlan a Ujang (2005) prostřednictvím svých výzkumů tvrdí, že využívání informačních technologií v oblasti ř́zení lidského kapitálu v sobě nese př́nosy pro korporaci v podobě zvyšování kvality, efektivity, efektivnosti a produktivity lidských zdrojů. Nicméně informační technologie a informační systémy vyžadují aktivní zapojení všech zaměstnanců korporace. Nguyen a Chang (2017) v rámci svých zjištění přišli s verifikovanou hypotézou, že existuje pozitivně významný vztah mezi snížením nákladů korporace a rozhodnutím o externím využívání HR aktivit, činností a procesů. Důvodem dále může mimo jiné být např́íklad nedostatek odborných znalostí, zkušenosti či informací v oblasti ř́zení lidského kapitálu. Kim a Ryu (2017) zjistili, že dobře navržená politika konceptu Work-life balance má za následek zvyšování spokojenosti a motivace zaměstnanců, která mimo jiné vede k větší korporátní angažovanosti. I když koncept Work-life balance nemusí být vždy dobře implementován a to zejména díky agresivní korporátní kultuře. Caillier (2017) v této souvislosti dále tvrdí, že pakliže korporace aktivně implementuje koncept Work-life balance do své personální politiky, mají její zaměstnanci pozitivní pocit, že se o ně jejich korporace stará a určitým způsobem o ně pečuje.

Dnešní globální a turbulentní (podnikatelské) prostředí tak s sebou přináší nejen zajímavé a významné výzvy i př́ležitosti, ale také bohužel hrozby či ohrožení pro každý (podnikatelský) subjekt. Management se tak musí někdy rozhodovat bez dostatečného množství informací či v situaci nejistoty, ba dokonce možného rizika. Snahou je být konkurenceschopný, efektivně výkonný a ziskový subjekt. Je tedy zřejmé, že pokud to podmínky nejen poskytovatele zdravotních služeb umožňují, realizuje management rozmanité aktivity, kroky a činnosti tak, aby bylo dosaženo navržené a stanovené strategie. Tuto tezi mimo jiné také potvrzuje testovaná výzkumná hypotéza, která přišla se zjištěním, že neexistuje závislost mezi počtem zaměstnanců a implementací stanoveného moderního trendu v oblasti řízení lidských zdrojů u vybraných poskytovatelů zdravotních služeb. Vybraní poskytovatelé zdravotních služeb tak realizují své záměry a plány s ohledem na interní, ale také externí podmínky a situaci. V tomto kontextu lze mimo jiné uvažovat také o právní formě a vlastníkovi vybraného poskytovatele zdravotních služeb (ministerstvo, kraj, město, obec, církev nebo soukromá právnická osoba - např́íklad Agel), což ovšem nebylo primárně cílem tohoto príspěvku, ale odráží tato skutečnost zejména interní podmínky a situaci vybraného poskytovatele zdravotních služeb.

Výzkumná otázka číslo 1 (VO1): Jakým způsobem je, v dnešním turbulentním a globálním prostředí, vnímána stále rostoucí tendence značky/brandu poskytovatele zdravotních služeb v České republice?

Struktura oslovených HR manažerů u vybraných poskytovatelů zdravotních služeb v České republice je znázorněna v níže uvedené tabulce (Tabulka 3). Počet oslovených respondentů v rámci realizovaného kvalitativního výzkumu - polostrukturovaných interview - byl dvanáct. Jednalo se tak o HR specialisty anebo HR manažery vybraných poskytovatelů zdravotních služeb v České republice. 
Tabulka 3: Struktura oslovených HR manažerů u vybraných poskytovatelů zdravotních služeb v České republice

\begin{tabular}{|c|c|c|c|}
\hline Kategorie dle členění Evropské unie & $\begin{array}{c}\text { Interval (hranice) počtu } \\
\text { zaměstnanců }\end{array}$ & Absolutní četnost & Relativní četnost \\
\hline $\begin{array}{c}\text { Mikro poskytovatel zdravotních } \\
\text { služeb }\end{array}$ & $\begin{array}{c}\text { méně než } 10 \\
\text { zaměstnanců }\end{array}$ & 2 & $16,33 \%$ \\
\hline $\begin{array}{c}\text { Malý poskytovatel zdravotních } \\
\text { služeb }\end{array}$ & $\begin{array}{c}\text { méně než 50 } \\
\text { zaměstnanců }\end{array}$ & 6 & $50,00 \%$ \\
\hline $\begin{array}{c}\text { Střední poskytovatel zdravotních } \\
\text { služeb }\end{array}$ & $\begin{array}{c}\text { méně než 250 } \\
\text { zaměstnanců }\end{array}$ & 3 & $25,00 \%$ \\
\hline $\begin{array}{c}\text { Velký poskytovatel zdravotních } \\
\text { služeb }\end{array}$ & $\begin{array}{c}250 \text { a více } \\
\text { zaměstnanců }\end{array}$ & $\mathbf{1 2}$ & $\mathbf{1 0 0 , 0 0 \%}$ \\
\hline $\begin{array}{c}\text { Celkový počet oslovených respondentů u vybraných } \\
\text { poskytovatelů zdravotních služeb v České republice }\end{array}$
\end{tabular}

Zdroj: Vlastní zpracování

Většina oslovených HR specialistů anebo HR manažerů u vybraných poskytovatelů zdravotních služeb $\mathrm{v}$ České republice $\mathrm{v}$ rámci realizovaných polostrukturovaných interview uvedla, že je dnes problém najít na trhu práce dostatečně kvalifikovaného, zkušeného a loajálního zaměstnance. V této souvislosti dále HR specialisté anebo HR manažeři uvedli, že se tedy neomezují pouze na český trh práce, nýbrž nabízejí pracovní možnost a uplatnění lékařưm či nelékařským zdravotnickým zaměstnanců ze Slovenské republiky, Polska nebo Ukrajiny. Je tedy na místě zajímat se o to, jak je daný poskytovatel zdravotních služeb vnímán očima potenciálních zaměstnanců na trhu práce jako zaměstnavatel. Zda hodnoty, výhody, personální oblasti či činnosti, které jsou pro zaměstnance důležité, poskytovatel zdravotních služeb skutečně nabízí anebo alespoň v rámci personálního marketingu deklaruje či nikoliv.

Ovšem z primárního výzkumu Maršíkové a Myslivcové (2016) vyplývá, že jedním $\mathrm{z}$ důležitých nástrojů, který ovlivňuje spokojenost, motivaci, angažovanost, stabilizaci a následně také širrení značky/brandu zaměstnavatele stávajícími zaměstnanci je výše jejich mzdy či platu.

Pokud jde o samotnou významnost značky/brandu poskytovatele zdravotních služeb, je pro 91,67 \% oslovených HR specialistů anebo HR manažerů evaluována jako maximálně důležitá a to nejen v souvislosti s nedostatečnou kvalifikací potenciálních zaměstnanců, ale také v kontextu biologického stárnutí populace a to nejen v České republice.

K této oblasti se vyjadřuje také Matušínská (2015), která prezentuje neoddiskutovatelný fakt, že demografické stárnutí je základní charakteristikou současného vývoje všech populací evropského typu.

V kontextu stanovené výzkumné otázky číslo jedna dále všichni oslovení respondenti shodně souhlasí s tím, že dobrá značka/brand zaměstnavatele určitým způsobem zvyšuje míru zájmu, reakcí a odpovědí potenciálních zaměstnanců. Tato skutečnost může bezesporu snižovat náklady poskytovatele zdravotních služeb v oblasti recruitmentu a může tak urychlovat celý tento proces. S tezí, že značka/brand poskytovatele zdravotních služeb spojuje všechny zaměstnance, vyslovuje souhlas celkem 83,33 \% oslovených HR specialistů anebo HR manažerů. Nicméně tato myšlenka se určitě může promítat také do následujících oblastí, jako např́iklad: (1) kolik nových potenciálních zaměstnanců se k danému poskytovateli zdravotních služeb hlásí na doporučení stávajícího lékaře, stávajícího nelékařského zdravotnického zaměstnance či jiného stávajícího zaměstnance, (2) kolik stávajících zaměstnanců vybraného poskytovatele zdravotních služeb by svého zaměstnavatele 
doporučilo novým potenciálním zaměstnancům, (3) kolik stávajících zaměstnanců daného poskytovatele zdravotních služeb od něho dobrovolně odchází a tak podobně.

\section{Závěr}

Lidský kapitál zahrnuje schopnosti, znalosti, dovednosti a zkušenosti zaměstnanců každé korporace. Význam lidských zdrojů je umocňován ve znalostní společnosti, ve které se znalosti stávají rozhodujícím výrobním faktorem. Proto je řízení lidských zdrojů nezbytnou součástí strategie každé dnešní moderní korporace - firmy, instituce, organizace, podniku, úřadu, společnosti (Novotný a Duspiva 2013).

Př́ispěvek byl zaměřen na oblast řízení lidských zdrojů u vybraných poskytovatelů zdravotních služeb v České republice v kontextu současných moderních personálních trendů. Jeho cílem tak bylo na základě obsahové analýzy sekundárních informačních zdrojů, zejména pak vědecké literatury, definovat současné moderní trendy, které charakterizují oblast dnešního řízení lidských zdrojů a následně tyto definované trendy analyzovat HR specialisty anebo HR manažery u vybraných poskytovatelů zdravotních služeb na území České republiky. Celkem tak bylo definováno osm současných moderních personálních trendů, se kterými se dále pracovalo v oblasti výzkumu primárního. Jmenovitě se jednalo o aktivní péči o (zdraví) zaměstnanců, brand zaměstnavatele, diversity management, e-Recruitment a sociální sítě, globální pracovní prostředí, informační technologie a systémy, outsourcing vybraných personálních činností či procesů a Work-life balance. Aktivní péče o (zdraví) zaměstnanců je důležitá zejména proto, že bez lidských zdrojů by jakýkoliv korporace firma, instituce, organizace, podnik, úřad, společnost - nemohla fungovat a existovat. Brand zaměstnavatele dnes nabývá na svém významu a důležitosti a to nejen $v$ souvislosti s nedostatkem kvalifikovaných zaměstnanců na trhu práce. Politika rovných př́ležitostí a možností pro každého člověka a zaměstnance či filosofie konceptu diversity managementu v sobě skrývá řadu předností a výhod pro fungování celé korporace - firmy, instituce, organizace, podniku, úřadu, společnosti, ale také významně posiluje brand zaměstnavatele. Je jasné, že se Internet a informační technologie aktivně promítají také do oblasti řízení lidského kapitálu. Online nábor (e- Recruitment) a sociální sítě jsou HR specialisty či HR manažery stále více implementovány do korporátní personální praxe. Globální pracovní prostředí se dnes, ve 21. století, stává nezbytnou součástí fungování jakékoliv korporace, ale samozřejmě i samotného trhu práce. Informační systémy a technologie mění, zlepšují či zefektivňují různé postupy a procesy a i nadále budou usnadňovat pracovní aktivity, činnosti a úkoly nejen samotným zaměstnancům. Mezi čtyři základní kategorie v oblasti řízení lidských zdrojů, kterou bývají často outsourcovány lze zařadit všeobecné personální aktivity a činnosti, transakční činnosti, činnosti v oblasti lidského kapitálu, nábor a výběr lidských zdrojů. V rámci zvyšování motivace, spokojenosti a loajality zaměstnanců mohou nejen vybraní poskytovatelé zdravotních služeb, ale jakékoliv korporace, aktivně využívat koncept Worklife balance, který je založen na základní ideji rovnováhy mezi soukromým a pracovním životem každého zaměstnance. Zjišt'ování primárních dat bylo provedeno pomocí dotazníkového šetření (celkem čtyřicet sedm respondentů) a polostrukturovaných interview (celkem dvanáct HR specialistů anebo HR manažerů vybraných poskytovatelů zdravotních služeb v České republice). Dotazníkové šetření bylo realizováno ve dvou fázích tak, aby se podařilo zajistit co možná nejobjektivnější pohled na zkoumanou problematiku a také zmenšit a zmírnit limit výzkumu spočívající v nízké návratnosti dotazníkového šetření. Celková návratnost tak představovala dvacet pět procent. V rámci naplnění cíle př́spěvku byla definována jedna výzkumná hypotéza a jedna výzkumná otázka. Prostřednictvím verifikace stanovené výzkumné hypotézy bylo zjištěno, že neexistuje statisticky významná závislost mezi využíváním současného moderního trendu v oblasti řízení lidských zdrojů a počtem 
zaměstnanců u vybraného poskytovatele zdravotních služeb v České republice. V návaznosti na charakterizovanou výzkumnou otázku většina oslovených HR specialistů anebo HR manažerů u vybraných poskytovatelů zdravotních služeb v České republice dále uvedla, že je dnes problém najít na trhu práce dostatečně kvalifikovaného, zkušeného a loajálního zaměstnance. Je tedy určitě na místě zajímat se o to, jak je daný poskytovatel zdravotních služeb vnímán očima potenciálních zaměstnanců na trhu práce jako zaměstnavatel. Výzkumem zvolené vybrané současné moderní personální trendy u poskytovatelů zdravotních služeb v České republice se jeví jako vhodně stanovené a i nadále tak lákají k další výzkumné aktivitě.

\section{Poděkování}

Tento př́spěvek vznikl za podpory interního grantu - FaME RO/2016/12 „Řízení efektivnosti zdravotních organizací".

\section{Literatura}

[1] AMMENDOLIA, C., P. CÔTÉ, C. CANCELliERE, J. D. CASSIDY, J. HARTVIGSEN, E. BOYLE, S. SOKLARIDIS, P. STERN and B. AMICK III, 2016. Healthy and productive workers: using intervention mapping to design a workplace health promotion and wellness program to improve presenteeism. BMC Public Health, 16(1): 1190. DOI: 10.1186/s12889-016-3843-x.

[2] ARMSTRONG, M. a S. TAYLOR, 2015. Řizení lidských zdrojů: moderní pojetí a postupy. 13. vyd. Praha: Grada Publishing, 920 s. ISBN 978-80-247-5258-7.

[3] ARMSTRONG, M., 2011. Řizení pracovního výkonu v podnikové praxi: cesta $k$ efektivitě a výkonnosti. 1. vyd. Praha: Fragment, 400 s. ISBN 978-80-253-1198-1.

[4] BACKHAUS, K. and S. TIKOO, 2004. Conceptualizing and researching employer branding. Career Development International, 9(5), 501-517. ISSN. 1362-0436. DOI: 10.1108/13620430410550754.

[5] BELCOURT, M., 2006. Outsourcing - the benefits and the risks. Human Resource Management Review, 16(2), 269-279. ISSN 1053-4822.

[6] BRYAN, M. L. and A. SEVILLA, 2017. Flexible working in the UK and its impact on couples' time coordination. Review of Economics of the Household, 01-23. ISSN 15737152 .

[7] CAILliER, J. G., 2017. Do Work-Life Benefits Enhance the Work Attitudes of Employees? Findings from a Panel Study. Public Organization Review, 17(1), 393408. ISSN 1573-7098.

[8] DAHLAN, N., J. DAHLAN and M. UJANG, 2005. Reality of information systems in human resource management and knowledge management: An exploratory study on police reporting System. In Proceedings of the 3rd International Conference on Education and Information Systems: Technologies and Applications, EISTA 2005. Orlando, FL; United States, 45-47. ISBN 0-901800-29-5.

[9] DOBUSCH, L., 2017. Gender, Dis-/ability and Diversity Management: Unequal Dynamics of Inclusion? Gender, Work and Organization, 24(5), 487-505. DOI: 10.1111/gwao.12159.

[10] EBY, L. T., W. J. CASPER, A. LOCKWOOD, C. BORDEAUX and A. BRINLEY, 2005. Work and family research in IO/OB: content analysis and review of the literature (1980-2002). Journal of Vocational Behavior, 66(1), 124-197. ISSN 0001-8791. 
[11] EGEROVÁ, D. and L. EGER, 2017. Recruitment through the use of corporate websites A comparative study. In Proceedings of the 29th International Business Information Management Association Conference - Education Excellence and Innovation Management through Vision 2020: From Regional Development Sustainability to Global Economic Growth 2017. Vienna, Austria: International Business Information Management Association (IBIMA), 1137-1149. ISBN 978-0-9860419-7- 6.

[12] FRIED, B. J. and M. D. FOTTLER, 2008. Human resources in healthcare: Managing for success. 3rd ed. Chicago: Health Administration Press, 545 pages. ISBN 978-1-56793299-7.

[13] CHUANG, C-H. and H. LIAO, 2010. Strategic human resource management in service context: taking care of business by taking care of employees and customers. Personnel Psychology, 63(1), 153-196. ISSN 1744-6570. DOI: 10.1111/j.1744-6570.2009.01165.x.

[14] JOHNSON, G., P. WILDING and A. ROBSON, 2014. Can outsourcing recruitment deliver satisfaction? A hiring manager perspective. Personnel Review, 43(2), 303-326. ISSN 0048-3486.

[15] KASHIVE, N. and V. T. KHANNA, 2017. Study of early recruitment activities and employer brand knowledge and its effect on organization attractiveness and firm performance. Global Business Review, 18(3), 172-190. ISSN 0973-0664.

[16] KIM, J. S. and S. RYU, 2017. Employee satisfaction with work-life balance policies and organizational commitment: a Philippine study. Public Administration and Development, 37(1), 260-276. ISSN 1099-162X.

[17] KLAAS, B. S., J. A. MCCLENDON and T. W. GAINEY, 2001. Outsourcing: the impact of organizational characteristics. Human Resource Management, 40(2), 125-138. ISSN 1099-050X.

[18] KOCIANOVÁ, R., 2012. Personální rrizení: východiska a vývoj. 2. vyd. Praha: Grada, 149 s. ISBN 978-80-247-3269-5.

[19] KUNERTH, B. and R. MOSLEY, 2011. Applying employer brand management to employee engagement. Strategic HR Review, 10(3), 19-26. ISSN 1475-4398.

[20] LADKIN, A. and D. BUHALIS, 2016. Online and social media recruitment: Hospitality employer and prospective employee considerations. International Journal of Contemporary Hospitality Management, 28(2), 327-345. ISSN 0959-6119.

[21] MANOHARAN, A. and M. SINGAL, 2017. A systematic literature review of research on diversity and diversity management in the hospitality literature. International Journal of Hospitality Management, 66(1), 77-91. DOI: 10.1016/j.ijhm.2017.07.002.

[22] MARIANI, M. G., M. CURCURUTO and M. ZAVALLONI, 2016. Online recruitment: The role of trust in technology. Psicologia Sociale, 11(2), 199-209. ISSN 1827-2517.

[23] MARŠÍKOVÁ, K. a S. MYSLIVCOVÁ, 2016. Personální marketing - atributy stabilizace zaměstnanců. Acta academica karviniensia, 16(2), 28-40. ISSN 2533-7610.

[24] MATUŠÍNSKÁ, K., 2015. Marketingové vnímání vymezeného segmentu zákazníků na trhu finančních služeb. Acta academica karviniensia, 15(1), 119-129. ISSN 2533-7610.

[25] NAEGLER, H., 2014. Personalmanagement im Krankenhaus. 3., erw. und aktualisierte Aufl. Berlin: Medizinisch Wissenschaftliche Verlagsgesellschaft, 421 Seiten. ISBN 9783-95466-103-9. 
[26] NGO, H. Y., S. FOLEY and R. LOI, 2009. Family friendly work practices, organizational climate, and firm performance: a study of multinational corporations in Hong Kong. Journal of Organizational Behavior, 30(5), 665-680. ISSN 1099-1379.

[27] NGUYEN, T. T. T. and M-L. CHANG, 2017. Antecedents of human resources outsourcing decision in Vietnam. Personnel Review, 46(4), 702-717. ISSN 0048-3486.

[28] NOVOTNÝ, J. a P. DUSPIVA, 2013. Rozhodování manažera při uvolňování pracovníků z podniku. Acta academica karviniensia, 13(2), 119-129. ISSN 2533-7610.

[29] PYNES, J. and D. N. LOMBARDI, 2011. Human resources management for health care organizations: a strategic approach. 1st ed. San Francisco: Jossey-Bass, 424 pages. ISBN 978-0-470-87355-7.

[30] RYAN, A. M. and J. L. WESSEL, 2015. Implications of a changing workforce and workplace for justice perceptions and expectations. Human Resource Management Review, 25(1), 162-175. ISSN 1053-4822.

[31] SCHULTZ, A. B. and D. W. EDINGTON, 2007. Employee Health and Presenteeism: A Systematic Review. Journal of Occupational Rehabilitation, 17(3), 547-579. ISSN 1573-3688.

[32] SILVA, C., S. SILVA and D. MARTINS, 2017. The LinkedIn platform in human resources recruitment. In Proceedings of the 29th International Business Information Management Association Conference - Education Excellence and Innovation Management through Vision 2020: From Regional Development Sustainability to Global Economic Growth 2017. Vienna, Austria: International Business Information Management Association (IBIMA), 3942-3953. ISBN 978-0-9860419-7- 6.

[33] SUSOMRITH, P. and A. BROWN, 2017. The core processes adopted for outsourcing HRM in Australia and its outcomes. Management Decision, 55(7), 1521-1535. DOI: 10.1108/MD-05-2016-0333.

[34] TUSSAYADIAH, I. P. and D. R. FESENMAIER, 2009. Mediating the tourist experience access to places via shared videos. Annals of Tourism Research, 36(1), 24-40. ISSN 0160-7383.

[35] VODÁK, J. a A. KUCHARČÍKOVÁ, 2011. Efektivní vzdělávání zaměstnanců. 2. vyd. Praha: Grada, 237 s. ISBN 978-80-247-3651-8.

[36] WAHBA, M. and D. ELMANADILY, 2015. Employer branding impact on employee behavior and attitudes applied study on pharmatecual in Egypt. International Journal of Management and Sustainability, 4(6), 145-162. ISSN 2306-9856.

[37] WINDSCHEID, L., L. BOWES-SPERRY, J. MAZEI and M. MORNER, 2017. The Paradox of Diversity Initiatives: When Organizational Needs Differ from Employee Preferences. Journal of Business Ethics, 145(1). 33-48. DOI: 10.1007/s10551-015-28641.

[38] WISE, L. R. and M. TSCHIRHART, 2000. Examining Empirical Evidence on Diversity Effects: How Useful Is Diversity Research for Public Sector Managers? Public Administration Review, 60(5), 386-394. ISNN 1540-6210. 